\title{
Ahmadreza Djalali, MD, PhD is Dying
}

\author{
Frederick M. Burkle, Jr., MD, MPH, PhD (Hon.), DTM, FAAP, FACEP $\odot$
}

Harvard Humanitarian Initiative, Harvard University \& T.H. Chan School of Public Health, Cambridge, Massachusetts USA; Woodrow Wilson International Center for Scholars, Washington, DC USA;

Institute of Medicine, National Academy of Sciences, Washington, DC USA;

Prehospital and Disaster Medicine, WADEM, Madison, Wisconsin USA

\section{Correspondence: \\ Frederick M. Burkle, Jr. \\ Professor (Ret.), Senior Fellow \& Scientist \\ Harvard Humanitarian Initiative \\ Harvard University \& T.H. Chan School of Public Health \\ 14 Story Street 2nd Floor \\ Cambridge, Massachusetts 02138 USA \\ E-mail: fburkle@hsph.harvard.edu}

\section{Conflicts of interest: none}

Keywords: Ahmadreza Djalali, MD, PhD; humanitarian; incarceration; Iran

Received: June 11, 2020

Accepted: June 25, 2020

doi:10.1017/S1049023X20000874

(C) World Association for Disaster and

Emergency Medicine 2020.

\section{Editor-in-Chief Note:}

Dr. Djalali is a well-known member of the international disaster medicine community. He is a man always with a smile and sincere in seeking the best for all mankind. His now extremely prolonged imprisonment without due process to allow him to defend himself represents one of the most profound inhumane acts on the globe. His torture and starvation are beyond comprehension for the international health and medicine community as well as all men and women. The pictures that accompany this editorial are published with proper permissions and have been authenticated as untouched from the originals.

Burkle FM Jr. Ahmadreza Djalali, MD, PhD is dying. Prehosp Disaster Med. 2020;35(5):475-476.

"While in antiquity the law rivals medicine, there is not in it that extraordinary solidarity which makes the physician at home in any country... "Sir William Osler, Aequanimitas, 1906

Ahmadreza Djalali is the Swedish-Iranian academic researcher who studied abroad at the Università del Piemonte Orientale (CRIMEDIM) Research Center in Emergency and Disaster in Italy to bring new information on disaster management back to Iran. He shared in the multicultural aspects of this outstanding program with fellow students from many countries. On his first trip back to Iran to arrange for teaching conferences on disaster medicine, he was arrested and sentenced to death in 2017 for refusing to become a spy for Iran and forced under torture to sign a bogus confession. Multiple agencies and organizations including UN Human Rights experts, Amnesty International, Scholars at Risk, and over 130 Nobel Laureates have urgently called for his release and the lifting of his death sentence. In 2017, The Lancet published a plea for his release, and while it alerted his fellow physicians

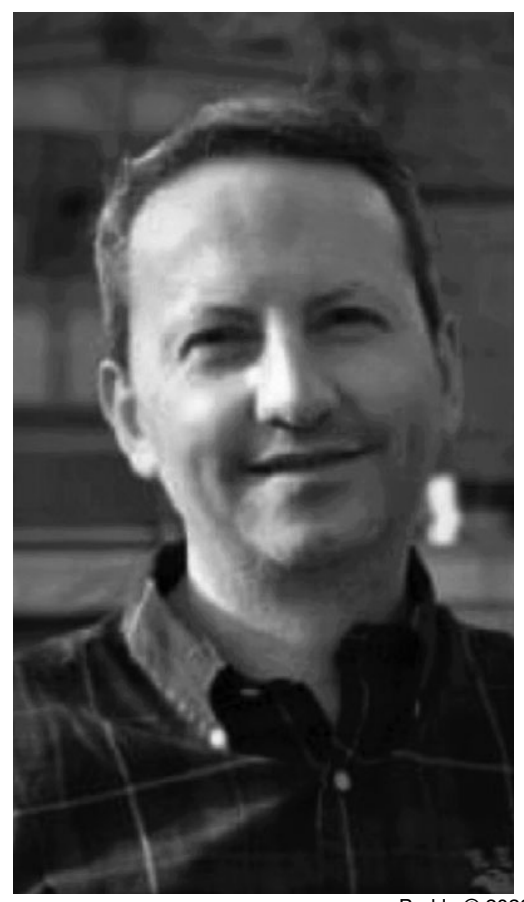

Burkle ㅇ 2020 Prehospital and Disaster Medicine

Figure 1. Ahmadreza Djalali, MD, PhD in 2017. 


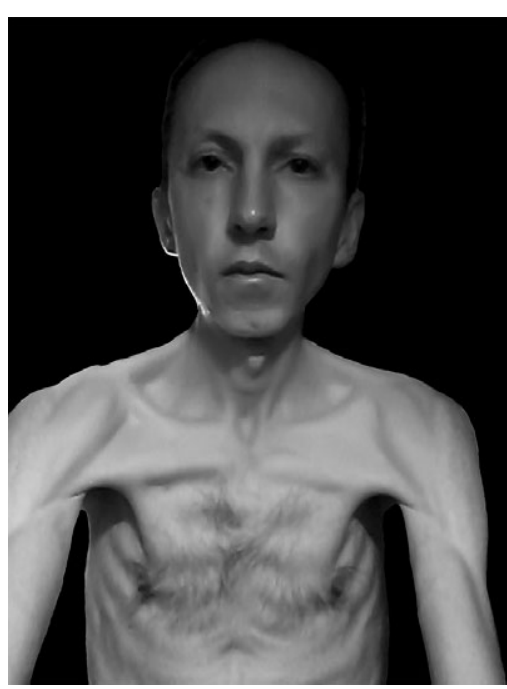

Burkle (C) 2020 Prehospital and Disaster Medicine

Figure 2. Ahmadreza Djalali, MD, $\mathrm{PhD}$ in 2020.

in Iran of his false sentencing, it was ignored by the Iranian government. ${ }^{1}$ Today, one of our own is near death (Figure 1 and Figure 2).

Both the World Association for Disaster and Emergency Medicine (WADEM) and Prehospital and Disaster Medicine (PDM) must speak out to bring immediate attention to the worsening and desperate plight of Ahmadreza Djalali, one of our own members and frequent scientific contributor to the science of disaster medicine.

Whatever political advantage Iran thought they might gain by his incarceration has had the opposite effect to what was intended. Upon his death, academic institutions world-wide, that support the over 70,000 Iranian graduate students and scholars studying abroad each year, will be increasingly reluctant to participate for fear those graduates will suffer a similar fate once they return.

After over 1,500 days of incarceration, his health has dramatically worsened making him increasingly vulnerable to Iran's second COVID-19 surge, crowded prison conditions, and increasing mental and physical torture.

Physicians, such as Ahmad, are neutral, respected, and protected under the Geneva Convention and International Humanitarian Law. Ahmad's release and return to his wife and two children in Sweden, where he is a citizen, must occur now before he dies. $\mathrm{He}$ is of no use to Iran in prison. Iran will benefit greatly in the eyes of the world if he is immediately and compassionately released. His plight is our plight. I ask that every member of WADEM and reader of PDM speak out in any manner possible for his immediate freedom.

\section{Supplementary Material}

To view supplementary material for this article, please visit https:// doi.org/10.1017/S1049023X20000874

\section{Reference}

1. Della Corte F, Burkle FM Jr., Gallardo AP, Ragazzoni L. Ahmadreza Djalali: questions everyone must ask. Lancet. 2017;389(10084):2101. 